\title{
Needs Analysis in Curriculum Design: Language Needs of Tourism Students*
}

\section{Semahat AYSU**}

\author{
Fatma Hülya ÖZCAN***
}

\begin{abstract}
In this study, the main aim was to reveal English language needs of tourism students for their future profession. Regarding the obtained needs from students, graduates, content experts and employers in tourism sector, goals and objectives of Vocational English Course were set. The data were collected through needs analysis questionnaires and semi-structured interviews. 70 students in the school where the researcher works, 112 graduates of Tourism and Hotel Management program, 9 content experts and 51 employers working in tourism sector answered the questionnaire. 8 students, 11 graduates, 2 content experts and 5 employers took part in semi-structured interviews voluntarily. After the questionnaire was administered to four groups of participants, the obtained data were analyzed through SPSS 20. On the other hand, while analyzing the qualitative data, the recordings were transcribed for the analysis of data by the researcher. Then, a list of codes developed by Wen (2010) was drawn on for coding. The results indicated that 4 language skills (reading, listening, speaking and writing) were important for tourism students, but particularly listening and speaking language skills for their future profession were emphasized.
\end{abstract}

Keywords: English for specific purposes (ESP), Needs analysis (NA), Goals and objectives, Vocational course for tourism.

\footnotetext{
* Ethics committee approval for this study was obtained from the Namık Kemal University Rectorate Scientific Research and Publication Ethics Committee, dated 27/03/2018 and numbered T2018-3. This study is a condensed summary of the PhD dissertation entitled as "Designing An ESP Curriculum for Tourism and Hotel Management Program at a Vocational School: A Case Study of Şarköy Vocational School" and completed by Semahat AYSU in September 2019.

** Orcid ID: https://orcid.org/0000-0001-6431-9983, Dr., Tekirdağ Namık Kemal University, Turkey, semahat-aysu@hotmail.com

*** Orcid ID: https://orcid.org/0000-0002-2327-8430, Prof. Dr., Anadolu University, Turkey, fozcan@anadolu.edu.tr
} 


\section{INTRODUCTION}

English for Specific Purposes (ESP) is "the teaching and learning of English as a second or foreign language where the goal of the learners is to use English in a particular domain" (Paltridge \& Starfield, 2013, p.2). That is ESP means teaching English to the learners in order to use it in their academic and professional lives (Basturkmen, 2006). But ESP is not a product but "an approach to language teaching in which all decisions as to content and methods are based on the learner's reason for learning" (Hutchinson \& Waters, 1987, p.19) and it should be differentiated from teaching general English. As Dudley-Evans and St John (1998) discuss, specific needs of the learners, methodology and activities of a profession and appropriate language are three common characteristics to all ESP courses. ESP class is therefore designed on the basis of learners' needs and purposes (Dudley-Evans \& St John, 1998; Hutchinson and Waters, 1987; Kennedy \& Bolitho, 1984; Kim, 2008; Otilia- Simion, 2012). These identified needs and purposes of learners will guide the course content and in turn, this course content will cater to the interests of learners.

Curriculum design for ESP classes has been the subject of numerous studies for various disciplines so far, and they have showed the importance of English language teaching for specific purposes (Al-Khatib, 2005; Cutting, 2012; Jasso-Aguilar, 2005; Wang, 2007; Wen, 2010). Since NA is the first step of curriculum design (Basturmen, 2003; Brindley, 1989; Brown, 1995; Dudley-Evans, 2001; Hedge, 2000; Hutchinson and Waters, 1987; Nunan, 2001), the growing body of literature assessed language needs of the learners for their future profession, evaluated ESP curricula and suggested changes (Alfehaid, 2011; Ulucay and Demirel, 2011).

\section{Needs analysis (NA) for an ESP class}

Needs Analysis (NA) has been regarded as the first step in various contexts of language teaching by different scholars (Benesch, 1996; Brindley, 1989; Brown, 1995; DudleyEvans, 2001; Dudley- Evans \& St. John, 1998; Graves, 1996; Hedge, 2000; Hutchinson \& Waters, 1987; Kennedy \& Bolitho, 1984; Nunan, 1988; Nunan, 2001) since it appeared in language education with the development of Communicative Language Teaching (CLT) in 1970s. NA process consists of "observation of classroom methodology, reflecting on local conditions and resources, review of educational policy, and interviews and questionnaire surveys among teachers, students, advisory staff, and the inspectorate" (Hedge, 2000, p. 343). That is, NA is a must for general language courses, English for Specific Purposes courses and English for Academic Purposes courses. The following key questions should be answered via needs analysis before the course is designed and teaching materials are selected: "What do students need to do with English? Which of the skills do they need to master and how well? Which genres do they need to master, either for comprehension or production purposes?" (Dudley-Evans, 2001, p. 131).

While conducting needs analysis, the questions are same for the courses but the answers vary (Hutchinson \& Waters, 1987). For instance, a number of studies were carried out in tourism sector to reveal the language needs of tourism personnel in order to design a 
course. Jasso-Aguilar (2005) investigated language needs of housekeepers, Sullivan and Girginer (2002) conducted a NA study in order to develop a course for pilots and air traffic controllers. Cutting (2012) analyzed English language needs of learners who wanted to work as ground staff and Prachanant (2012) carried out a study for the needs of tourism employees working in international tour companies. Besides the studies on language needs of tourism staff in the workplace, there are also studies about the needs of tourism students studying at the university conducted by Afzali and Fakharzadeh, 2009; Choi, 2010; Coşkun, 2009; Diken, 2006; Wen, 2010. A growing body of research implies that language needs of learners differ from one another in different contexts. This tends the researcher to carry out this study to address the needs of a particular group of students taking not only students' but also graduates', content experts' and employers' needs into consideration.

\section{Previous Studies on Curriculum Design for Tourism Classes}

A number of studies were carried out so as to find out English language needs of tourism staff in their workplace. Jasso-Aguilar (2005) investigated language needs of housekeepers, Sullivan and Girginer (2002) conducted a NA study in order to develop a course for pilots and air traffic controllers. Cutting (2012) analyzed English language needs of learners who planned to work as ground staff and Prachanant (2012) carried out a study for the needs of tourism employees working in international tour companies. They will be summarized below.

Jasso-Aguilar (2005) carried out a study in order to investigate the housekeepers' tasks at a hotel, the language they need while they were working, their perceptions about their language needs and whether their performance was affected by the insufficient language skills. Data were collected via observations, unstructured interviews and questionnaires from 3 housekeepers, one human resources person, executive housekeeper, housekeeper assistants and supervisors. That is, the researcher triangulated both data collection methods and sources. She argued the use of various sources demonstrated perceived needs and objective needs in a different way. For example, while hotel maids considered that the lack of English language skills did not affect their tasks, the administrative staff thought that the hotel housekeepers should develop their English language skills to be involved in the conversations with the guests. Another conclusion from the study was that triangulation of methods and sources helped the curriculum designers to include the learners' views.

Sullivan and Girginer (2002) conducted NA study in order to develop a course in which pilots and air traffic controllers were taught English in the Turkish context. They collected both quantitative and qualitative data through questionnaires, interviews, observation in the airport tower and recording transactions between two groups. The results showed that needs of both groups of learners would be making requests, pronouncing and comprehending numbers, listening to multiple interlocutors, understanding who is talking to whom, intervening, understanding words which are specific to aviation and participating in conversations. 
In another study, Cutting (2012) investigated English language needs of learners who planned to work as ground staff (as security guards, ground handlers, catering staff and bus drivers) in European airports. The aim of the study was to collect authentic data based on real life in order to create dialogues for the multimedia course for English language learners and to show the students "examples of real interactions to sensitise them to non-native-speaker inappropriate forms and code-switching, World Englishes and spoken grammar features, such as incomplete and incoherent utterances, short pauses, longer silences, repeating and recasting" (Cutting, 2012, p. 5). In other words, field notes were collected to develop ESP materials and to design exercises.

As a result, functional-situational speech events were designed for the learners who had restricted grammar but needed to know basic grammar.

A similar study was carried out by Prachanant (2012) in order to investigate the needs of tourism employees. 40 participants, who worked in international tour companies, took part in this research and they answered the questionnaire about the participants' language needs, functions and problems. According to the results, speaking skill was the most important skill for the employees in tourism industry and followed by listening skill. Needs with regard to the language functions were: giving information, providing services and offering help. Finally, the most frequent listening problem was being unable to understand foreign accents, the most frequent speaking problem was using inappropriate words and expressions in speaking, the most frequent reading problem was having inadequate vocabulary in reading and the most frequent writing problem was lack of grammar knowledge.

Having reviewed the literature related to the language needs of tourism staff in the workplace so far, we will focus on the studies related to the needs of tourism students studying at the university.

Choi (2010) conducted a study with students whose major was tourism at a two-year college in order to investigate their needs of tourism English. Three groups of students participated in the study. The number of one group of students is 120 , who attended day classes and 40 students attended night classes and the final group consisted of 40 students, who worked on days and attended class at nights. The questionnaires were answered by the participants before the term started and after the term finished. Results showed that students thought that they lacked of grammar and communicative abilities, and they wanted to develop their speaking skills and they were instrumentally motivated as they wanted to learn English for their workplace.

In the study of exploring necessary writing skills for tourism students, Afzali and Fakharzadeh (2009) obtained 591 letter topics from 4 hb.com letters and websites. Then, a pilot study was conducted to shorten this long topic list and find out what difficulties people had when they were dealing with the travel agencies and hotels. Consequently, students were required to show the topics to the travel agencies and hotels in order to make them tick the most widely used topics with the customers. At the end of the pilotstudy, the number of topics was 103. Next, 14 travel agencies and 10 hotels were 
asked to what extent they used these topics in their correspondence with the customers. Finally, the frequency of the topics stated by the participants was estimated and inter rater reliability was conducted. Among these topics "reservation" was the most frequently marked topic, "thank you for your tour" and "announcement of special discount offer" were the second and third topics. They were followed by "complimentary letter to hotel, announcement of price reduction, announcement of price increase, apology after cancellation of order, bill of sale, complaint letter, congratulation for increased sale, follow-up letter to travel agency, apology for delay of refund, announcement of new discount, guarantee, reply to complaint, reply to inquiry, employment agreement, announcement of change of address, inquiry letter". These findings can be a direct reference to the curriculum and material development studies since learners' actual needs are the core of these studies but it focuses on only writing needs of tourism staff.

These various studies about the ESP curriculum development above showed that language needs of learners differ from one another in different contexts. This conclusion leads to identify the needs of our students taking students' felt needs, graduates', content experts' and employers' perceived needs. Such a study will appeal to specific needs of a particular group of students.

\section{Research Questions}

The main aim of this study is to identify the future needs of students studying in the program of Tourism and Hotel Management at a vocational school. Since a great number of ESP studies have showed that language needs of learners differ from one another in different context (Afzali \& Fakharzadeh, 2009; Al-Khatib, 2005; Choi, 2010; Coşkun, 2009; Cutting, 2012; Diken, 2006; Gatehouse, 2001; Jasso-Aguilar, 2005; Prachanant, 2012; Sullivan \& Girginer, 2002; Ulucay \& Demirel, 2011; Wang, 2007; Wen, 2010), the needs of the learners will be identified. Therefore, within this framework, the following research questions will be answered in this study.

Research question 1: What are the language needs of students studying Tourism and Hotel Management at a vocational school according to the views of students, graduates, content experts and employers?

Research question 2: What do the participants suggest to meet tourism students' language needs?

\section{METHOD}

The main impetus behind this study is the teaching experience of the researcher. She has been teaching vocational English to tourism students in a Vocational School of a state university, which offers a 2-year associate degree. There are two types of English courses: General English (GE) and vocational English (ESP) courses. The course content of GE course is developed and taught by Application and Research Centre for Distance Learning of the university based on National Qualification Framework suggested by Council of Higher Education (YÖK). That is, GE course is taught through distance 
education during 2 terms in the first year of the students. Vocational English course, where the problem arises, is designed and taught by the course instructor. Although the necessary foreign language competences are suggested by National Qualification Framework for Higher Education in Turkey for vocational school students as follows: "Monitoring the developments in the field and communicating with peers by using a foreign language at least at a level of European Language Portfolio A2 General Level" (YÖK, 2011), the specific needs of tourism students have not been examined; besides, learning outcomes have not been defined, and therefore, a particular curriculum is not followed in this course. So, she decided to identify the future language needs of tourism students in order to set achievable goals and objectives based on these needs. Her decision was based on the suggestions and comments of some scholars (Berwick, 1989; Dudley-Evans and St. John, 1998; Hutchinson \& Waters, 1987; Richards, 2001; Schleppegrell \& Bowman, 1986) about the lack of language needs of learners for their future profession and the need to identify these language needs and to offer a course, which will serve their future needs. This, in turn, will motivate students to learn English and ESP course will be successful. Consequently, the aim of this study is to present first step of curriculum design and discuss the findings related to language needs of tourism students.

Regarding the purpose of the current study and data collection and analysis process, this study drew on the convergent parallel design, which is one of the mixed methods research designs (Creswell, 2012). That is, during the Spring term of 2017/2018 academic year quantitative data through questionnaires and qualitative data via semistructured interviews were gathered at the same time. After data were analyzed separately, results from both data sets were merged and interpreted.

\section{Participants}

It is suggested NA should be carried out with the individuals who are related to the situation or the profession (Graves, 1996; Long, 2005; Luka, 2007). Following the suggestions of researchers, needs analysis was conducted with not only learners but also content experts, language teachers, employers and graduates in order to include different sources (both the insiders and outsiders) for the reliability of data. Ethics committee approval for this study was obtained from the Namı Kemal University Rectorate Scientific Research and Publication Ethics Committee, dated 27/03/2018 and numbered T2018-3

Therefore, participants in this study were 242 people from various groups 70 students, 112 graduates, 9 content experts and 51 employers) and they all answered needs analysis questionnaire. Participants among each group were chosen through purposive sampling method. Participants of semi-structured interviews were chosen on the basis of their willingness. While they were participating in the quantitative part of the study, they were asked whether they would like to participate in the interview. If they marked the item as "yes", they were interviewed. There were 27 individuals who took part in the qualitative part of the study and were volunteers for the interviews. 
The first group of the participants was the current students who were studying Tourism and Hotel management in a Vocational School of a state university. There were 70 students in this group. While 59 students were second-year students, 11 out of 70 were first-year students. The second group of participants was the graduates. This group consisted of 112 participants. The questionnaire was sent to 211 graduates via a social media tool (facebook) but only 112 of them responded to the questionnaire. The third group of participants included 9 content experts from the University. 5 content experts are lecturers, who teach in Tourism and Hotel Management Program and 4 of them are English instructors who had teaching experience in the vocational English course in tourism and hotel management program. The fourth group was employers in travel agencies, hotels, restaurants or cafes and car rental. Only 51 out of 123 employers answered the questionnaire.

\section{Instruments}

\section{Questionnaire}

The students' needs analysis questionnaire was developed based on the literature review, researcher's own experience in language teaching and the instruments of Basturkmen (1998), Chan (2001), Coşkun (2009), Ekici (2003), Güleç (2013) and Özyel, Özdemir and Kalajahi (2012). After the content validity and face validity of this questionnaire were evaluated by ten experts (seven lecturers in the program of Tourism and Hotel Management and three English language instructors), pilot study was conducted with 10 students. The number of participants was decided regarding the suggestions of Büyüköztürk (2005), who proposes that between 10 and 20 participants should take part in the pilot test. In order to show internal consistency of the questionnaire, reliability of the questionnaire was measured and Cronbach Alpha coefficient was found as .94. Parallel questionnaires for graduates, content experts and employers were made up changing the wording (See Appendix A for Students' Needs Analysis Questionnaire).

Mackey and Gass (2005) believe that questionnaires should be given to the students in their native language if they are not proficient enough in the foreign language. Regarding the suggestions of Mackey and Gass (2005), the questionnaire was developed and administered in Turkish to prevent ambiguity as participants are all in elementary-level. Therefore, participants comprehended questionnaire items and provided answers easily as they were Turkish native speakers.

This questionnaire consisted of 2 parts. The first part included 7 questions, which were related to participants' background information. The second part consisted of eight questions. Six questions aimed to reveal students' English language needs, language functions and topics in a vocational English class, but last two questions included activities in the language class and teaching materials.

\section{Semi-Structured Interviews}


In this study interview topics were listed as follows: students' language needs for their job, difficulties they have encountered in language classes, strengths and weaknesses they have experienced in language learning and their suggestions for language learning. Open questions for each group of participants are "Do you think that English will be important for your future job?" (for students); "In which area of tourism sector do your work?" (for graduates); "To what extent is English as a foreign language important for tourism industry?" (for content experts and employers). While preparing interview questions, Seidman's (2006, p. 84) suggestions such as “avoiding leading questions and asking open-ended questions" and Dörnyei's (2007) rules like "avoid (a) leading questions ('It was frustrating, wasn't is....?') and (b) loaded or ambiguous words ad jargon" were taken into consideration (p.138). Before using interview questions for the main study, it was piloted and necessary changes were made (See Appendix B for semistructured interview questions).

\section{Procedure}

Before the data collection, necessary permission from the Ethics Committee was obtained. The questionnaire was administered to current students after their English class at university. The questionnaire was sent to the graduates via a social media tool and e-mailed to the content experts. Finally, employers were visited in their workplace. After all questionnaires were administered to the participants, the obtained data from four groups of participants were fed into a computer through SPSS 20 and analyzed by using Descriptive Statistics.

Participants of semi-structured interviews were chosen on the basis of their willingness. While they were answering questionnaire, they were asked whether they would like to participate in the interview and then they were interviewed. Interviews with students and content experts were conducted in the researcher's office and graduates were interviewed through the phone and the employers participated in the interviews in their workplace during the Spring term of 2017/2018 academic year. All the interviews were conducted by researcher and they were all tape recorded. When qualitative data collection process ended, recordings were transcribed and the list of codes developed by Wen (2010) was drawn on for coding. The underlying reason why Wen's coding was used was that the current study had the same purpose which aimed to find out language needs of learners in detail and used the same NA approach which is suggested by Dudley-Evans and St John (1998). Therefore, data gathered through the semi-structured interviews were similar to Wen's data. Also, inter-rater reliability for data coding was calculated as $85 \%$. This was accepted agreement between the raters (the researcher and her supervisor).

\section{RESULTS}

In this part, the findings of questionnaire and semi-structured interviews will be showed based on the views of students, graduates, content experts and employees. Both 
receptive and productive language needs of tourism students with their sub-skills will be presented. Finally, participants' suggestions to meet these needs will be demonstrated.

\section{The importance of speaking sub-skills}

As it is seen in Table 1 below, the speaking sub-skills which are ranked as important by students, graduates, content experts and employers are: "expressing yourself, expressing what you have comprehended, conducting telephone conversation with foreigners asking advice or help, conducting face-to-face conversations with foreigners asking advice or help, asking questions, answering questions, correct pronunciation, maintaining a conversation, dealing with communication problems, dialogue, summarizing, comparing, solving problems, criticizing, wording quickly and describing things when you don't know the exact word" are the most important skills among each participant groups.

Table 1

Participants' perceived speaking subskills needs

\begin{tabular}{|c|c|c|c|c|}
\hline Items & $\begin{array}{c}\text { Students' } \\
\text { perceptions } \\
(\%) \\
\text { Important } \\
\text { /Very } \\
\text { important }\end{array}$ & $\begin{array}{c}\text { Graduates' } \\
\text { perceptions } \\
(\%) \\
\text { Important } \\
\text { /Very } \\
\text { important }\end{array}$ & $\begin{array}{c}\text { Content } \\
\text { experts' } \\
\text { perceptions } \\
(\%) \\
\text { Important } \\
\text { /Very } \\
\text { important }\end{array}$ & $\begin{array}{c}\text { Employers' } \\
\text { perceptions } \\
(\%) \\
\text { Important } \\
\text { /Very } \\
\text { important }\end{array}$ \\
\hline Answering questions & 84.1 & 92.9 & 100 & 90.2 \\
\hline Asking questions & 85.7 & 89.3 & 88.9 & 88.2 \\
\hline Comparing & 70 & 74.1 & 100 & 68.6 \\
\hline $\begin{array}{l}\text { Conducting face-to-face } \\
\text { conversations with foreigners } \\
\text { asking advice or help }\end{array}$ & 80 & 92.9 & 33.3 & 94.1 \\
\hline $\begin{array}{l}\text { Conducting telephone } \\
\text { conversations with foreigners } \\
\text { asking advice or help }\end{array}$ & 85.7 & 90.2 & 33.3 & 92.2 \\
\hline Correct pronunciation & 82.9 & 87.5 & 100 & 94.1 \\
\hline Criticizing & 65.7 & 72.3 & 88.9 & 58.8 \\
\hline $\begin{array}{l}\text { Dealing with communication } \\
\text { problems }\end{array}$ & 82.6 & 91.1 & 11.1 & 88.2 \\
\hline
\end{tabular}




\begin{tabular}{lcccc}
\hline $\begin{array}{l}\text { Describing things when you } \\
\text { don't know the exact word }\end{array}$ & 81.4 & 89.3 & 44.4 & 84.3 \\
$\begin{array}{l}\text { Dialogue } \\
\begin{array}{l}\text { Expressing what you have } \\
\text { comprehended }\end{array}\end{array}$ & 97.6 & 90.2 & 88.9 & 92.2 \\
$\begin{array}{l}\text { Expressing yourself } \\
\text { Maintaining a conversation }\end{array}$ & 77.1 & 92 & 11.1 & 88.2 \\
$\begin{array}{l}\text { Making presentations related to } \\
\text { the profession }\end{array}$ & 74.3 & 75 & 100 & 94.1 \\
$\begin{array}{l}\text { Participating discussions related } \\
\text { to the profession }\end{array}$ & 78.6 & 78.6 & 33.3 & 84.3 \\
$\begin{array}{l}\text { Solving problems } \\
\text { Summarizing }\end{array}$ & 78.6 & 87.5 & 11.1 & 82.4 \\
\begin{tabular}{l} 
Wording quickly \\
\hline
\end{tabular} & 79.1 & 83 & 100 & 78.4 \\
\hline
\end{tabular}

On the one hand, these show that the staff in tourism needs to have at least basic speaking skills such as expressing yourself, asking questions or answering questions. On the other hand, they also need high level speaking skills such as expressing what you have comprehended, summarizing, comparing or criticizing. The underlying reasons might be that staff in tourism both has to conduct day-to-day communication with the guests and have to carry out interaction related to their profession.

\section{The importance of reading sub-skills}

Table 2 shows that students, graduates, content experts and employers perceive the following reading sub-skills as important: "Reading in detail and understand the whole text, reading quickly for general understanding, reading and then translating into the native language, reading booklets, brochures and catalogues, reading legal documents, reading instructions in the institution, guessing the meaning of unknown words from context, reading business letters, e-mail messages and fax messages, reading tickets and itineraries, reading application forms, reservation forms and invoices, reading reports, reading scientific journals". 
Table 2

Participants' perceived reading subskills needs

\begin{tabular}{|c|c|c|c|c|}
\hline Items & $\begin{array}{c}\text { Students' } \\
\text { perceptions } \\
(\%) \\
\text { Important } \\
\text { /Very } \\
\text { important }\end{array}$ & $\begin{array}{c}\text { Graduates' } \\
\text { perceptions } \\
(\%) \\
\text { Important } \\
\text { /Very } \\
\text { important }\end{array}$ & $\begin{array}{c}\text { Content } \\
\text { experts' } \\
\text { perceptions } \\
(\%) \\
\text { Important } \\
\text { /Very } \\
\text { important }\end{array}$ & $\begin{array}{c}\text { Employers' } \\
\text { perceptions } \\
(\%) \\
\text { Important } \\
\text { /Very } \\
\text { important }\end{array}$ \\
\hline $\begin{array}{l}\text { Guessing the meaning of unknown } \\
\text { words from context }\end{array}$ & 74.3 & 79.5 & 77.8 & 76 \\
\hline $\begin{array}{l}\text { Reading and then translating into } \\
\text { the native language }\end{array}$ & 84.3 & 81.2 & 66.7 & 68.6 \\
\hline $\begin{array}{l}\text { Reading application forms, } \\
\text { reservation forms and invoices }\end{array}$ & 75.7 & 78.6 & 66.7 & 84 \\
\hline $\begin{array}{l}\text { Reading booklets, brochures and } \\
\text { catalogues }\end{array}$ & 80 & 79.5 & 100 & 64.7 \\
\hline $\begin{array}{l}\text { Reading business letters, e-mail } \\
\text { messages and fax messages }\end{array}$ & 77.1 & 79.5 & 88.9 & 82 \\
\hline $\begin{array}{l}\text { Reading in detail and } \\
\text { understanding the whole text }\end{array}$ & 91.4 & 80.4 & 100 & 72.5 \\
\hline $\begin{array}{l}\text { Reading instructions in the } \\
\text { institution }\end{array}$ & 78.6 & 81.2 & 77.8 & 88.2 \\
\hline Reading legal documents & 78.6 & 80.4 & 77.8 & 80.4 \\
\hline $\begin{array}{l}\text { Reading quickly for general } \\
\text { understanding }\end{array}$ & 72.9 & 59.8 & 88.9 & 60.8 \\
\hline Reading reports & 72.9 & 78.6 & 100 & 72 \\
\hline Reading scientific journals & 65.7 & 64.3 & 77.8 & 52.9 \\
\hline Reading tickets and itineraries & 75.7 & 79.5 & 88.9 & 74.5 \\
\hline
\end{tabular}

As it is understood from the reading sub-skills above, tourism students need to comprehend all profession-specific documents in English such as booklets, brochures, ticket, application forms or scientific journals. In this current study one of the most important reading sub-skills is "guessing the meaning of unknown words from the context". Therefore, some techniques to teach guessing the meaning of a word from the context might be included in the curriculum. 


\section{The importance of listening sub-skills}

In table 3, it is demonstrated that the most important listening sub-skills are: "Listening for the main idea/key points, obtaining specific information, deducing the meaning of unfamiliar words or word groups, understanding the people from non-English and English speaking countries, listening for translating, understanding conversations on the phone, understanding complex sentences, listening for discriminating intonation and stress patterns, listening to natural speech, recognizing the speaker's attitude, listening to radio, TV, and internet broadcast and recognizing speech organization patterns" based on the views of students, graduates, content experts and employers about the importance of listening sub-skills.

Table 3

Participants' perceived listening subskills needs

\begin{tabular}{|c|c|c|c|c|}
\hline Items & $\begin{array}{c}\text { Students' } \\
\text { perceptions } \\
(\%) \\
\text { Important } \\
\text { /Very } \\
\text { important }\end{array}$ & $\begin{array}{c}\text { Graduates' } \\
\text { perceptions } \\
(\%) \\
\text { Important } \\
\text { /Very } \\
\text { important }\end{array}$ & $\begin{array}{c}\text { Content } \\
\text { experts' } \\
\text { perceptions } \\
(\%) \\
\text { Important } \\
\text { /Very } \\
\text { important }\end{array}$ & $\begin{array}{c}\text { Employers' } \\
\text { perceptions } \\
(\%) \\
\text { Important } \\
\text { /Very } \\
\text { important }\end{array}$ \\
\hline $\begin{array}{l}\text { Guessing the meaning of } \\
\text { unfamiliar words or word groups }\end{array}$ & 82.9 & 84.8 & 66.7 & 72.5 \\
\hline $\begin{array}{l}\text { Listening for discriminating } \\
\text { intonation and stress patterns }\end{array}$ & 78.6 & 83 & 100 & 82 \\
\hline Listening for specific information & 82.9 & 92.9 & 88.9 & 88.2 \\
\hline $\begin{array}{l}\text { Listening for the main idea/key } \\
\text { points }\end{array}$ & 85.7 & 88.4 & 88.9 & 92 \\
\hline Listening for translating & 80 & 83.9 & 100 & 74 \\
\hline Listening to natural speech & 78.3 & 85.7 & 88.9 & 92.2 \\
\hline $\begin{array}{l}\text { Listening to the radio, } \mathrm{TV} \text {, and the } \\
\text { internet broadcast }\end{array}$ & 74.3 & 75 & 88.9 & 62.7 \\
\hline $\begin{array}{l}\text { Recognizing speech organization } \\
\text { patterns (e.g. lecture, } \\
\text { announcement) }\end{array}$ & 74.3 & 82.1 & 100 & 76.5 \\
\hline Recognizing the speaker's attitude & 77.1 & 84.8 & 100 & 86.3 \\
\hline Understanding complex sentences & 78.6 & 84.8 & 44.4 & 78 \\
\hline
\end{tabular}




\begin{tabular}{lcccc}
\hline $\begin{array}{l}\text { Understanding conversations on } \\
\text { the phone }\end{array}$ & 80 & 89.3 & 77.8 & 92.2 \\
$\begin{array}{l}\text { Understanding the people from } \\
\text { non-English and English speaking } \\
\text { countries (Understanding } \\
\text { different accents) }\end{array}$ & 81.4 & 85.7 & 88.9 & 86.3 \\
\hline
\end{tabular}

The following listening sub-skill is "understanding the people from non-English and English speaking countries" is compatible with the spread of English around the world. Staff in tourism, therefore, need to understand the people speaking world Englishes rather than the people speaking British and American English.

\section{The importance of writing sub-skills}

Acording to Table 4, the most important writing sub-skills regarding the views of students, graduates, content experts and employers are as follows: "Filling in forms, writing CV, adapting appropriate tone and style, using appropriate vocabulary, taking notes on phone, writing e-mail messages, spelling correctly, using correct punctuation, preparing brochures, writing responses to enquiries, writing reports, writing summary and writing letters" are ranked as the most important writing sub-skills.

Table 4

Participants' perceived writing subskills needs

\begin{tabular}{lcccc}
\hline & $\begin{array}{c}\text { Students' } \\
\text { perceptions } \\
(\%)\end{array}$ & $\begin{array}{c}\text { Graduates' } \\
\text { perceptions } \\
\text { Important }\end{array}$ & $\begin{array}{c}\text { Content } \\
\text { experts' } \\
\text { perceptions } \\
\text { Items }\end{array}$ & $\begin{array}{c}\text { Employers' } \\
\text { perceptions } \\
\text { Important }\end{array}$ \\
$\begin{array}{lcccc}\text { /Very } \\
\text { important }\end{array}$ & $\begin{array}{c}\text { /Very } \\
\text { Important }\end{array}$ & $\begin{array}{c}\text { Important } \\
\text { /Very }\end{array}$ & $\begin{array}{c}\text { /Very } \\
\text { important }\end{array}$ \\
\hline $\begin{array}{l}\text { Adapting appropriate tone and } \\
\text { style }\end{array}$ & 84.1 & 71.4 & 88.9 & 76.5 \\
$\begin{array}{l}\text { Filling in forms (e.g. applications } \\
\text { and invoices) }\end{array}$ & 87.1 & 83 & 77.8 & 80.4 \\
$\begin{array}{l}\text { Preparing brochures } \\
\text { Spelling correctly }\end{array}$ & 47.1 & 56.2 & 77.8 & 51 \\
$\begin{array}{l}\text { Taking notes while talking on the } \\
\text { phone }\end{array}$ & 76.8 & 75 & 77.8 & 68.6 \\
\hline
\end{tabular}




\begin{tabular}{lcccc}
\hline Using appropriate vocabulary & 81.4 & 83 & 66.7 & 84.3 \\
Using correct punctuation & 67.1 & 68.8 & 100 & 58.3 \\
Writing CV & 84.3 & 85.7 & 88.9 & 72.5 \\
Writing e-mail messages & 72.9 & 81.2 & 77.8 & 84.3 \\
Writing letters & 64.3 & 69.6 & 66.7 & 54.9 \\
Writing reports & 68.6 & 73.2 & 77.8 & 62.7 \\
Writing responses to enquiries & 77.1 & 75.9 & 77.8 & 74.5 \\
Writing summary & 74.3 & 62.5 & 77.8 & 60.8 \\
\hline
\end{tabular}

\section{The Suggestions of Participants to Meet the Students' Needs}

Participants' suggestions gathered via semi-structured interviews were categorized using the coding system of Wen (2010). And a new theme "other extra curricular activities" is also added to Wen's system. Consequently, 10 themes and 27 codes are revealed (See Table 5).

\section{Table 5}

Themes and codes suggested by participants

Themes Codes

\begin{tabular}{ll}
\hline General Knowledge Skills & Speaking practices \\
\hline Curriculum orientation & Group work \\
& Pair work \\
& Differentiated learning activities \\
& The use of films or videos \\
& Simulation/role play activities \\
& Actual use of language in real situations \\
& The use of language games \\
& Vocabulary and fixed phrases teaching \\
& Structure teaching \\
& The use of graded books \\
& The lack of general English knowledge \\
& Writing- Spelling \\
\end{tabular}




\begin{tabular}{ll}
\hline Sociolinguistic competence & Different accents \\
\hline Strategic competence & Being fluent \\
\hline Educational institutions & The lack of class hour \\
& Student exchange program \\
& Face-to-face instruction \\
\hline Resources & The use of textbook \\
& The use of extra materials \\
\hline Facilities & The use of mobile phone applications \\
\hline Affective factors & Attitudes towards language learning \\
& Motivation \\
& Interest \\
\hline Other extra curricular activities & The use of social media tools \\
& Tours \\
& Conversation club \\
\hline
\end{tabular}

In Table 5, themes and codes consisted of general knowledge skills (speaking practices), curriculum orientation (group work, pair work, differentiated learning activities, the use of films or videos, simulation/role play activities, actual use of language in real situations and the use of language games), linguistic competence (vocabulary and fixed phrases teaching, structure teaching, the use of graded books, the lack of general English knowledge and writing-spelling), sociolinguistic competence (different accents), strategic competence (being fluent), educational institutions (the lack of class hour, student exchange program and face-to-face instruction), resources (the use of textbooks and the use of extra materials), facilities (the use of mobile phone applications), affective factors (attitudes towards language learning, motivation and interest) and other extracurricular activities (the use of social media tools, tours and conversation club).

In the following some excerpts from the interviews will be provided for each theme.

Video izlemek veya film izlemek bütün bunlar konuşmayı güçlendirir. (G5)- Watching videos or watching movies all makes the speaking [skill] strengthen. (general knowledge skills)

Öğrencilerin grup olarak derse katıldığı şeyler önemli. İster sizle ya da sizle değil de arkadaşlarıyla karşılıklı olarak konuşsa iş hayatından ya da normal bir dialog olsa onun için daha iyi bir tecrübe olacağı düşünüyorum. (S2)- It is important that students participate in the lesson as a group. I think it would be a better experience for him if he talks to you or to his friend and it might be a dialogue from the workplace or daily life. (Curriculum orientation) 
Kelimelerle pratik hani günlük hayatta kullanılabilecek böyle hani otelde veya cafede. Zaten belli hani müşterinin ne için geldiği belli. İşte fiyat soracak ne kadar kalacak işte ödemeyi alayım diyecek. İşte "Can I take the payment?" söyleyebilmesi lazım. (E1)Practice with words, words which might be used in daily conversations in a hotel or in a café. It is already known why a customer comes. He will ask the price and how long he will stay and he will take the payment. He should know and be able to say "Can I take the payment?". (Linguistic competence)

Bizde olduğu gibi şive farkı yani American İngilizcesi ile normal İngiltere İngilizcesi farklı. Buralarda sıkıntı yaşıyorum. Bunların öğretilmesi gerekli. (S2) - As in our language, there are differences in the accents. In other words, American English and British English are different from each other. I have trouble with this issue. They need to be taught. (Sociolinguistic competence)

Ama şöyle bir şey başlangıç da bir dil seviyesi, pratiği olduğu takdirde hani yabancı bireyler içinde olduğu takdirde 1 ay içinde normal konuşma düzeyine geliyor ama orta düzey diyen birisi ki benim kuzenim mesela İngilizce okuyor. İngilizcesi benden çok daha iyi ama pratik olduğu zamanlarda ben ondan daha seri konuşuyorum, yani daha akıcı konuşuyorum çünkü içerisindeyim. Sürekli yabancılarlayım. Hani artık onu düşünmeden normal ana dil gibi konuşabiliyoruz, ama sektör içinde olmayınca olmuyor. (E5)- But something like that. If a person' language level is beginning and he does practices with foreigners, he starts to speak in one month. But a person who says my English level is intermediate, for example my cousin, is studying English [at university] and his English level is much better than mine, I speak more fluently than him. I speak much more fluently as I am using it. I am always with foreigners. We can speak it like a mother tongue without thinking of it but if you are not in the sector, you cannot speak it. (Strategic competence)

Yurtdışındaki turizm otel bölümü öğrencileriyle üniversiteler iletişime geçip karşılıklı öğrenciler ile iletişim ağıyla dillerini geliştirmesi için bir bağ oluşturabilirler. (S3)Universities might have a contact with the students studying tourism and hotel [management] in order to develop the language skills of students from both sides through this communication network. (Educational institutions)

Ders kitabı olabilir kurstaki kitap çok güzeldi hem keyif vericiydi hem eğlenceliydi hem de onları orada okuyorduk belli bir șey eğitim sonrasında ders sonrasında. Onun baya baya bir faydasını gördüm. Bu yüzden de zaten de okumayı ve yazmayı da sevdiğim için bu konuda gelişmiş oldum. (S4)- [I attended a course]. The textbook could be used. The textbook at the course was very good and it was both pleasant and fun. After the school or after the class, we read it there. It was useful for me. So, I improved [my English] as I like both reading and writing. (Resources)

Cep telefon uygulamaları olabilir aslında. Herkesin cep telefonu var ve sürekli İngilizce konuşan birisi olursa hani bir yerden sonra onu anlamak zorunda kalabiliriz. (G3)Mobile phone applications can actually be used. Everyone has a mobile phone and if there 
is someone who speaks English constantly, after a while, we have to understand him (Facilities)

Dersin öğrenciye sevdirilmesi gerekiyor, biraz daha eğlenceli geçebilir. Eğlenceli olursa öğrenci derse biraz daha ilgi duyar. (S2)- The course needs to be loved by the students, it should be enjoyable. If it is enjoyable, students will be more interested in the lesson. (Affective factors)

Conversation club olabilir, gelmek isteyen gelir zaten onlar da dinlemek için katılmak için geleceklerini düşünüyorum ben. 0 faydalı olur. (S6)- Conversation club might be organized. Who wants to come can attend. In other words, I think they will come to listen and attend [voluntarily]. It would be useful. (Other extra curricular activities)

As a conclusion, speaking and communicative skills are regarded as important skills and they should be developed. Furthermore, the use of role-plays or information-gap activities and problem solving activities were emphasized. There are also suggestions in regard with the number of contact hours, necessity of student Exchange programs and the importance of face-to-face instructions.

\section{CONCLUSION AND DISCUSSION}

In this study, the aim was to reveal what foreign language skills tourism students need for their future profession according to the views of students, graduates, content experts and employers in tourism sector.

As discussed in the literature review, needs analysis has been regarded as the first step in various contexts of language teaching by different scholars (Benesch, 1996; Brindley, 1989; Brown, 1995; Dudley-Evans, 2001; Dudley- Evans and St. John, 1998; Graves, 1996; Hedge, 2000; Hutchinson \& Waters, 1987; Kennedy \& Bolitho, 1984; Nunan, 1988; Nunan, 2001). For this reason, tourism students' needs were obtained through both questionnaires and semi-structured interviews in this study.

When the needs for productive language subskills were examined, it was revealed that the staff in tourism industry needs to have at least basic speaking skills. They also need high level speaking skills. Al-Khatib (2005) reports a similar finding that tourism personnel need English for communication purposes and they consider English an important means to communicate. When the needs for another productive language skill which was scrutinized, the results of the most important writing sub-skills in this study echo the findings of Afzali and Fakharzadeh (2009). In their study, they investigated the necessary writing skills for travel agencies and hotels. Additionally, important writing sub-skills such as writing and sending e-mail messages and faxes, making online ticketing and hotel booking are found as important in the study of Al-Khatib (2005).

Regarding the needs of reading subskills, tourism students need to comprehend all profession-specific documents in English such as booklets, brochures, ticket, application forms or scientific journals. This is in an agreement with the findings of the study of 
Ekici (2003), in which reading e-mail and fax messages and itineraries were found as the important skills for their future profession. Furthermore, Prachanant (2012) reveals that the most frequent reading problem is having inadequate vocabulary in reading. In this current study, one of the most important reading sub-skills is "guessing the meaning of unknown words from the context". Therefore, it should be noted that this subskill is an important need for tourism students.

The results of needs for listening subskills in this study are in accordance with the findings of the study of Ekici (2003), in which listening conversations on the phone and understanding native speakers were regarded as the most important listening skills. Moreover, the following listening sub-skill is "understanding the people from nonEnglish and English speaking countries" is compatible with the spread of English around the world. Staff in tourism, therefore, need to understand the people speaking World Englishes rather than the people speaking British and American English, which is similar to the findings of Cutting (2012), who identifies the needs of tourism staff and shows the tourism students some examples from real life such as non-native-speaker inappropriate forms and code-switching, World Englishes and spoken grammar features.

\section{IMPLICATIONS}

This study revealed the needs of tourism students for their future profession considering the views of students, graduates, content experts and employers in tourism sector. Based on these obtained needs, goals and objectives for the ESP course are proposed in the following.

The main goal of Vocational English Course for tourism students is to improve and develop both the receptive and productive English language skills, especially their listening and speaking skills for their future profession. In order to reach this main goal, the following objectives should be attained.

Objectives for receptive skills (listening and reading):

By the end of the course, students will be able to;

-identify the topic of the conversation/basic text types such as e-mails, messages, enquiries and letters of confirmation)

-identify the gist of the conversations, e-mails, messages, enquiries and letters of confirmation)

-identify the specific, predictable information in conversations, e-mails, forms (reservation), confirmation letters, invoices, tickets, itineraries etc.

-identify the key points of the announcements

-recognize different accents

-recognize speaker's attitude 
-translate from L1 to L2 or from L2 to L1 (basic concepts/sentences)

-guess the meaning of unfamiliar words

Objectives for productive skills (speaking and writing):

By the end of the course, students will be able to;

- produce intelligible language

-use simple techniques to start, maintain, and end a conversation.

-use simple polite forms of greeting and addressing; expressing thanks; expressing apologies; asking for satisfaction; asking for clarification.

-respond to suggestions, complaints

-give advice

-give information on basic field-related topics

-use compensation strategies

-carry out conversations in structured situations such as check-in and check-out procedures, taking orders, or carrying out housekeeping duties.

-fill in various forms such as application forms, invoices.

-produce formal, structured written texts to fulfill certain functions such as expressing thanks, apologies, asking and giving information, confirmation.

-write short, simple notes and messages.

\section{References}

Afzali, K., \& Fakharzadeh, M. (2009). A needs analysis survey: The case of tourism letter writing in Iran. ESP World, 1(8), 1-10.

Alfehaid, A.F.T. (2011). Developing an ESP curriculum for students of health sciences through needs analysis and course evaluation in Saudi Arabia. Unpublished PhD Dissertation, University of Leicester, School of Education, Leicester.

Al-Khatib, M.A. (2005). English in the workplace: An analysis of the communication needs of tourism and banking personnel. Asian EFL Journal, 7(2), 174-194.

Basturkmen, H. (1998). Refining Procedures: A Needs Analysis Project at Kuwait University. In Forum (Vol. 36, No. 4, p. n4).

Basturkmen, H. (2003). Specificity and ESP course design. RELC Journal, 34(1), 48-63.

Basturkmen, H. (2006). Ideas and options in English for specific purposes. London: Lawrence Erlbaum Associates.

Benesch, S. (1996). Needs analysis and curriculum development in EAP: An example of a critical approach. TESOL Quarterly, 30(4), 723-738. 
Berwick, R. (1989). Needs assessment in language programming: From theory to practice. In R. K. Johnson (Ed.), The Second Language Curriculum (pp.48-62). Cambridge: Cambridge University Press.

Brindley, G. (1989). The role of needs analysis in adult ESL programme design. In R. K. Johnson (Ed.), The Second Language Curriculum (pp. 63-78). Cambridge: Cambridge University Press.

Brown, J. D. (1995). The elements of language curriculum: A systematic approach to program development. Boston: Heinle \& Heinle Publishers.

Büyüköztürk, Ş. (2005). Anket geliştirme [Survey development]. Türk Eğitim Bilimleri Dergisi, 3(2), 133-151.

Chan, V. (2001, July). Determining students' language needs in a tertiary setting. In English teaching forum (Vol. 39, No. 3, pp. 16-27).

Choi, K. (2010). Needs analysis of students of Tourism English. In Proceeding of the 10th Conference of $P A A L$, 57-68. Seoul: Hanyang Women's University

Coşkun, A. (2009). An esp course for tourism students. English for Specific Purposes. World Online Journal for Teachers, 4(25), 1-15.

Council of Europe. (2001). Common European framework of reference for languages: Learning, teaching, assessment. Cambridge: Cambridge University Press.

Cutting, J. (2012). English for airport ground staff. English for Specific Purposes, 31, 3-13.

Diken, Ü. (2006). Gereksinim çözümlemesi kullanılarak uygulanan özel amaçlı dil (İngilizce) öğretimi (S.D.Ü. Eğirdir Meslek Yüksekokulu Örneği) [Special purpose language (English) teaching applied using needs analysis (S.D.Ü. Eğirdir Vocational School Example)]. Unpublished Master's Thesis. Süleyman Demirel University, Isparta.

Dörnyei, Z. (2007). Research methods in applied linguistics: Quantitative, qualitative, and mixed methodologies. Oxford: Oxford University Press

Dudley-Evans, T., \& St John, M. J. (1998). Developments in English for specific purpose: A multidisciplinary approach. Cambridge: Cambridge University Press.

Dudley-Evans, T. (2001). English for specific purposes. In R. Carter and D. Nunan (Eds.), The Cambridge Guide to Teaching English to Speakers of Other Languages (pp. 131-136). Cambridge: Cambridge University Press.

Ekici, N. (2003). A needs assessment study on English language needs of the tour guidance students of faculty of applied sciences at Başkent University: A case study. Unpublished Master's thesis, Middle East Technical University, Ankara.

Gatehouse, K. (2001). Key issues in English for specific purposes (ESP) curriculum development. The internet TESL journal, 7(10), 1-10.

Graves, K. (1996). Teachers as course developers. In K. Graves (Ed.), Teachers as course developers (pp.1-11). Cambridge: Cambridge University Press.

Güleç, H. (2013). Identifying English language needs of the Turkish national police academy students: A needs-based syllabus suggestion for law enforcement English course. Unpublished Master's thesis, Anadolu University, Eskişehir.

Hedge, T. (2000). Teaching and learning in the language classroom. Oxford: Oxford University Press.

Hutchinson, T., \& Waters, A. (1987). English for specific purposes: A learning-centered approach. Cambridge: Cambridge University Press.

Jasso-Aguilar, R. (2005). Sources, methods and triangulation in needs analysis: Acritical perspective in a case study of waikiki hotel maids. In M.H. Long (Ed.), Second Language Needs Analysis (pp. 127-158). Cambridge: Cambridge University Press. 
Kennedy, C., \& Bolitho, R. (1984). English for specific purposes. London: Macmillan.

Kim, D. (2008). English for occupational purposes: One language?. London: Continuum Books.

Long, M.H. (2005). Methodological issues in learner needs analysis. In M.H. Long (Ed.), Second Language Needs Analysis (pp.19-76). Cambridge: Cambridge University Press.

Luka, I. (2007). Development of students' English for special purposes competence in tourism studies at tertiary level. Polish Journal of Applied Psychology, 5, 1-18.

Mackey, A., \& Gass, S.M. (2005). Second language research: Methodology and design. London: Lawrence Erlbaum Associates.

Nunan, D. (1988). The learner-centred curriculum: A study in second language teaching. Cambridge: Cambridge University Press.

Nunan, D. (2001). Syllabus design. In M. Celce-Murcia (Ed.), Teaching English as a Second or Foreign Language (pp. 55-65). London: Heinle \& Heinle.

Otilia-Simion, M. (2012). The importance of teaching English in the field of tourism in universities. Annals of the 'Constantin Brancuşi' University of Targu Jiu, Economy Series, 2, 152-154.

Özyel, M., Özdemir, Ç., \& Kalajahi, S.A.R. (2012). Needs of an esp content: "needs analysis, curriculum \& unit design". Advances in Asian Social Science, 1(3), 265-281.

Paltridge, B., \& Starfield, S. (2013). The handbook of English for specific purposes. Oxford: WileyBlackwell.

Prachanant, N. (2012). Needs analysis on English language use in tourism industry. Procedia-Social and Behavioral Sciences, 66, 117-125.

Richards, J. C. (2001). Curriculum development in language teaching. Cambridge: Cambridge University Press

Seidman, I. (2006). Interviewing as qualitative research: A guide for researchersin education and the social sciences (3rd ed.). New York: Teachers College Press.

Sullivan, P., \& Girginer. H. (2002). The use of discourse analysis to enhance ESP teacher knowledge: an example using aviation English. English for Specific Purposes, 21, 397-404.

Schleppegrell, M., \& Bowman, B. (1986). ESP: Teaching English for specific purposes. Washington, DC: Center for Applied Linguistics.

Ulucay, S., \& Demirel, Ö. (2011). Perceptions of professionals, academicians and content and graduate students on designing an ESP curriculum for logistics department. Procedia Social and Behavioral Sciences, 15, 794-800.

Wang, A. (2007). Teaching aviation English in the Chinese context: Developing ESP theory in a nonEnglish speaking country. English for Specific Purposes, 26,121-128.

Wen, Z. (2010). Needs analysis of English language competences in vocational senior secondary education in Mainland China: A mixed methods inquiry. Unpublished PhD Dissertation. The Chinese University of Hong Kong, Hong Kong.

YÖK. (2011). Türkiye yükseköğretim yeterlilikleri çerçevesi [Turkey higher education qualifications framework]. Retrieved January 22, 2019, from: http://tyyc.yok.gov.tr/?pid=32. 
Ethics committee approval for this study was obtained from the Namık Kemal University Rectorate Scientific Research and Publication Ethics Committee, dated 27/03/2018 and numbered T2018-3.

\section{Statement of Contribution of Researchers to the Article:}

1st author contribution rate: $50 \%$

2nd author contribution rate: $50 \%$

Conflict of Interest Statement:

There is no conflict of interest.

Statement of Financial Support or Acknowledgment:

No financial support was received from any institution for this study. 